\title{
Mixed calcium-magnesium pre-nucleation clusters enrich calcium
}

\author{
Andreas Verch ${ }^{\mathrm{II}}$, Markus Antonietti ${ }^{\mathrm{II}}$ and Helmut Cölfen ${ }^{*}, \mathrm{I}$ \\ I Physical Chemistry, POB 714, Universität Konstanz, Universitätsstr. 10, D-78457 Konstanz, Germany

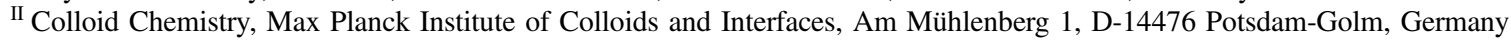

Received February 20, 2012; accepted August 31, 2012

Published online: October 15, 2012

\section{Pre-nucleation cluster / Amorphous calcium carbonate / Preferential ion binding / Mg-calcite / Non classical nucleation}

\begin{abstract}
It is demonstrated that magnesium and carbonate ions can form pre-nucleation clusters in analogy to calcium carbonate. If a mixed calcium and magnesium solution is brought in contact with carbonate ions, mixed pre-nucleation clusters form. The equilibrium constants for their formation are reported revealing that over the entire range of possible cation mixing ratios, calcium gets enriched over magnesium in the pre-nucleation clusters. This can explain high magnesium contents in amorphous calcium carbonate. However, this enrichment alone is not sufficient to explain the magnesium content of less than $41 \mathrm{~mol} \%$ which is found in magnesium calcite biominerals nucleated from seawater.
\end{abstract}

\section{Introduction}

Many marine invertebrates possess a shell or scaffold made of calcium carbonate. Most of these materials comprise the polymorphs aragonite and calcite. Laboratory experiments underline the importance of the $\mathrm{Mg}^{2+} / \mathrm{Ca}^{2+}-\mathrm{ra}-$ tio in the solution regarding both the morphology [1] and the polymorphism [2-4] of the precipitated material. High $\mathrm{Mg}^{2+} / \mathrm{Ca}^{2+}$-proportions $(>4: 1)$ for example lead to the formation of aragonite instead of calcite [2-4]. Aragonite usually does not include $\mathrm{Mg}^{2+}$, biogenic $\mathrm{Mg}$-calcite crystals can incorporate up to $41 \mathrm{~mol} \% \mathrm{Mg}^{2+}$ [5]. This integration of $\mathrm{Mg}^{2+}$ into calcite is of huge importance regarding the properties and the use of these minerals [6]. Artificial Mg-calcites, however, commonly contain merely 1-3 mol\% $\mathrm{Mg}^{2+}$ [7]. $\mathrm{Mg}^{2+}$ contents observed in synthetical amorphous $\mathrm{CaCO}_{3}(\mathrm{ACC})$ in contrast can be significantly higher. Wang et al. observed that carboxylated molecules might regulate and increase the $\mathrm{Mg}$-content in amorphous $\mathrm{CaCO}_{3}$ (ACC) [8].

It is meanwhile well accepted that many carbonate biominerals form via amorphous precursor phases [9] including those formed by marine organisms like sea urchins

* Correspondence author (e-mail: helmut.coelfen@uni-konstanz.de)
[10]. Although seawater contains about 5 times more $\mathrm{Mg}^{2+}$ than $\mathrm{Ca}^{2+}$ [11], Mg-calcites found in biominerals always contain less $\mathrm{Mg}$ as compared to $\mathrm{Ca}$ [5]. For example, a recent detailed analysis of an adult sea urchin spine revealed only 4 mol- $\% \mathrm{Mg}^{2+}$ [12]. Although it is clear that the calcite lattice can only accommodate a limited amount of $\mathrm{Mg}^{2+}$ ions, the reason for the enrichment of $\mathrm{Ca}^{2+}$ over $\mathrm{Mg}^{2+}$ can not only be due to lattice constraints. Otherwise, $\mathrm{Mg}$-calcite in marine biominerals would always contain the maximum possible $\mathrm{Mg}^{2+}$ amount, especially if it is considered that an amorphous precursor phase can accommodate a much higher $\mathrm{Mg}^{2+}$ amount, However, the maximum possible $\mathrm{Mg}^{2+}$ amount is obviously not the rule in marine magnesium calcite biominerals.

The reason for the possible $\mathrm{Ca}^{2+}$ over $\mathrm{Mg}^{2+}$ enrichment can already lie in the earliest formed species in a carbonate precipitation reaction. Although it had been known and extensively studied for already more than 80 years that the activities of $\mathrm{Mg}^{2+}$ and $\mathrm{Ca}^{2+}$ ions are significantly reduced in the presence of carbonate ions $[13,14]$ only recent analytical ultracentrifugation (AUC) [14] and cryo-TEM [15] experiments on $\mathrm{Ca}^{2+}$ and carbonate ion containing solutions have demonstrated that nmsized pre-nucleation clusters are present even before the onset of nucleation [16]. These clusters then aggregate $[14,15]$ in order to subsequently form ACC. It is therefore of interest to reveal the composition of $\mathrm{MgCO}_{3}$ and $\mathrm{CaCO}_{3}$ pre-nucleation species in a mixed $\mathrm{Mg}^{2+} / \mathrm{Ca}^{2+}$ carbonate precipitation system to address the question whether a $\mathrm{Ca}^{2+}$ enrichment is already found in these prenucleation species.

In this paper we present the result of AUC experiments on a pure $\mathrm{MgCO}_{3}$ solution as well as results from titration experiments on $\mathrm{Ca} / \mathrm{MgCO}_{3}$ systems with varying $\mathrm{Mg} / \mathrm{Ca}$ ratios. In these experiments $\mathrm{Mg}^{2+}$ and $\mathrm{Ca}^{2+}$ containing solutions were added to $10 \mathrm{~mm} \mathrm{Na}_{2} \mathrm{CO}_{3}$ solutions at a constant rate. The $\mathrm{Mg}^{2+}$ and $\mathrm{Ca}^{2+}$ potentials in solution were recorded by means of ion selective electrodes (ISE). The pH-value was kept constant by adding $\mathrm{NaOH}$ solution. Four different $\mathrm{Mg} / \mathrm{Ca}$-proportions were investigated ranging from $5: 1$, which corresponds to the $\mathrm{Mg} / \mathrm{Ca}$ proportion of seawater [11], over $1: 1$ and $1: 2$ down to $1: 5$. Additionally, we conducted experiments in the pure $\mathrm{MgCO}_{3}$ and $\mathrm{CaCO}_{3}$ system, respectively. 


\section{Results and discussion}

The development of the free $\mathrm{Ca}^{2+}$ concentration calculated from the recorded ion potentials is shown in Fig. 1a) for different $\mathrm{Mg} / \mathrm{Ca}$-ratios. A comparison of the nucleation times of the reference experiment in the absence of $\mathrm{Mg}^{2+}$ and those experiments in the presence of $\mathrm{Mg}^{2+}$ reveals that $\mathrm{Mg}^{2+}$ delays the nucleation of $\mathrm{CaCO}_{3}$ like typical low and high molecular nucleation inhibitors $[17,18]$. In general, it seems that the retardation of the nucleation is increasing with rising $\mathrm{Mg}^{2+}$ proportions. Interestingly, however, the strongest retardation of the nucleation is reproducibly observed in the experiments with the smallest applied $\mathrm{Mg}$ / Ca-ratios (1:5 and 1:2). This observation leads to the assumption that apparently two different nucleation pathways must be accessible at lower and higher $\mathrm{Mg}^{2+}$ contents. This phenomenon is denoted as bifurcation. A similar behaviour was recently also described for the precipitation of $\mathrm{CaCO}_{3}$ in the presence of sodium triphosphate [18]. Another important effect in the pre-nucleation stage is the increasing slope of the $\mathrm{Ca}^{2+}$ concentration with time prior to nucleation with rising $\mathrm{Mg}^{2+}$ proportions. This implies that less calcium is consumed to form $\mathrm{CaCO}_{3}$ pre-nucleation species at high $\mathrm{Mg} / \mathrm{Ca}$-ratios rather than at low $\mathrm{Mg}$ concentrations. As the number of carbonate ions is by orders higher than the added amount of $\mathrm{Ca}^{2+}$ and $\mathrm{Mg}^{2+}$ ions, it can be excluded that solely the increased consumption of carbonate ions is the cause for

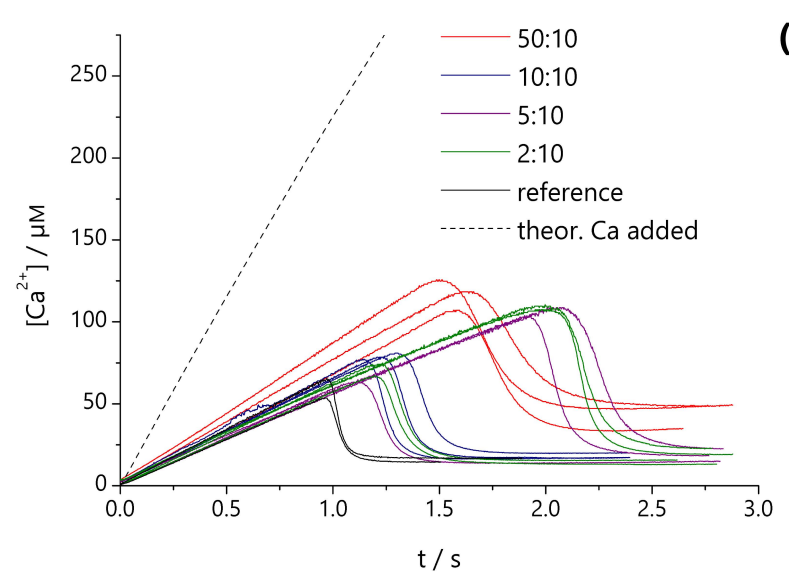

(a)

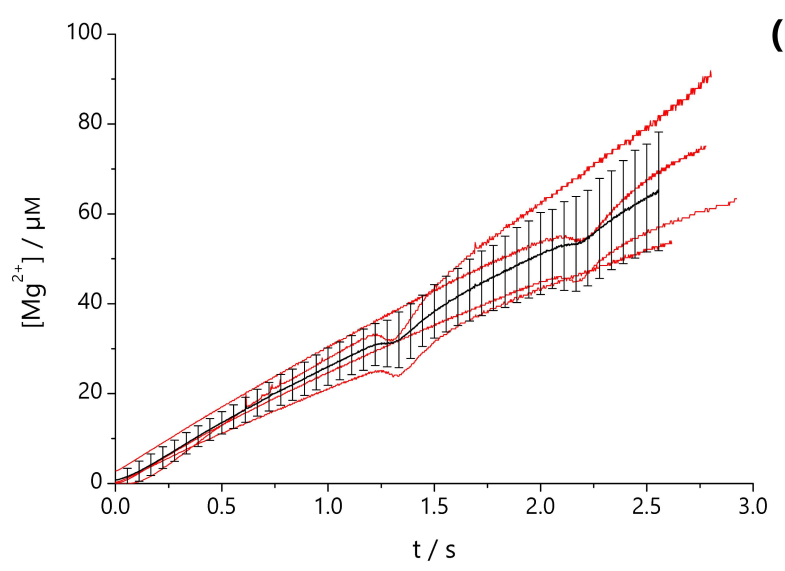

Fig. 1. (a) Development of the detected free calcium concentration and (b) progression of the measured $\mathrm{Mg}^{2+}$ concentration at a $\mathrm{Mg}^{2+}$ / $\mathrm{Ca}^{2+}$ ratio in the dosed solution of 2:10 (red, 4 measurements). this observation. Instead, this effect on the $\mathrm{CaCO}_{3}$ pre-nucleation equilibrium must be related to the presence of $\mathrm{Mg}^{2+}$. A quantitative analysis of the pre-nucleation equilibria is discussed in more detail further below.

Due to the wide range of $\mathrm{Mg}^{2+}$-concentrations applied in the different experiments, the progression of the free $\mathrm{Mg}^{2+}$ concentration is illustrated exemplarily for the experiment with an $\mathrm{Mg} / \mathrm{Ca}$-ratio of $2: 10$. Generally, it is important to note that the data from the magnesium ion selective electrode are less reproducible than those from the Ca-ISE, e.g. the slopes before the nucleation fluctuate significantly stronger between the single measurements (Fig. 1b). Hence, we used averaged values of different measurements to increase the statistical significance (not shown). At this low $\mathrm{Mg}^{2+}$ concentration the $\mathrm{CaCO}_{3} \mathrm{nu}-$ cleation can be identified by a sudden but short decline and a subsequent steeper rise in the free $\mathrm{Mg}^{2+}$ concentration. The initial drop of the $\mathrm{Mg}^{2+}$ concentration is presumably an artifact of the low selectivity of the $\mathrm{Mg}$ ion selective electrode towards $\mathrm{Ca}^{2+}$. At the highest $\mathrm{Mg} / \mathrm{Ca}-$ ratios this drop is not detected. However, in general the free amount of $\mathrm{Mg}^{2+}$ ions rises significantly faster after nucleation, while the $\mathrm{Ca}^{2+}$ concentration drops to the level, which corresponds to an equilibrium of amorphous $\mathrm{CaCO}_{3}$. This indicates a resolubilization of $\mathrm{Mg}^{2+}$ ions from pre-nucleation clusters upon nucleation. Two explanations for this observation are feasible: 1) The concentration of carbonate ions decreases rapidly after the nucleation, which triggers an adoption of the $\mathrm{MgCO}_{3}$ prenucleation equilibrium. Due to the large excess of carbonate ions, this possibility is unlikely. 2) $\mathrm{Mg}^{2+}$ ions, which were incorporated into then precipitated pre-nucleation species, are released during the mineralization process leading to an increased number of free $\mathrm{Mg}^{2+}$ ions (see below). After nucleation, the slope in the time dependence of free $\left[\mathrm{Mg}^{2+}\right]$ lowers a bit but is still steeper than before the nucleation, which likewise might be caused by both aforementioned reasons.

In all conducted experiments the $\mathrm{Mg}^{2+}$ ions influenced the polymorph, which was mineralized. Even at the lowest $\mathrm{Mg} / \mathrm{Ca}$-ratios solely aragonite was found. In contrast, in experiments in the absence of $\mathrm{Mg}^{2+}$ ions both calcite and vaterite were isolated $1 \mathrm{hr}$ after the nucleation. An influence of the two supposed nucleation modes at lower $\mathrm{Mg}^{2+} / \mathrm{Ca}^{2+}$-proportions on the precipitated mineral polymorph could not be identified; in both cases aragonite is formed. However, the reproducible differences in the nucleation times indicate that the mineralization proceeds via different intermediate species [18], though they cannot be identified by the technique we applied in this study. Indication for the formation of $\mathrm{Mg}$-calcite could not be found.

A quantitative analysis of the formation of $\mathrm{MgCO}_{3}$ and $\mathrm{CaCO}_{3}$ pre-nucleation species at different $\mathrm{Mg} / \mathrm{Ca}$-ratios is shown in Fig. 2. The formation constants $\mathrm{K}_{\mathrm{Ca}}$ and $\mathrm{K}_{\mathrm{Mg}}$ were calculated assuming the binding of one carbonate with one $\mathrm{Mg}^{2+}$ and $\mathrm{Ca}^{2+}$ ion, respectively. Here, the free cation concentrations were known from the recorded $\mathrm{Mg}^{2+}$ resp. $\mathrm{Ca}^{2+}$ ion potentials at the given $\mathrm{pH}=9.75$. $\left[\mathrm{CaCO}_{3}\right]$ resp. $\left[\mathrm{MgCO}_{3}\right]$ was accessible via the difference between added and detected cations prior to nucleation assuming a 1:1 stoichiometry between bound cations and 
anions. The free carbonate ion concentration could be determined via subtracting $\left[\mathrm{CaCO}_{3}\right]$ and $\left[\mathrm{MgCO}_{3}\right]$ from the known initial carbonate concentration.

$$
\mathrm{K}_{\mathrm{Ca}}=\frac{\left[\mathrm{CaCO}_{3}\right]}{\left[\mathrm{Ca}^{2+}\right]\left[\mathrm{CO}_{3}^{2-}\right]} ; \quad \mathrm{K}_{\mathrm{Mg}}=\frac{\left[\mathrm{MgCO}_{3}\right]}{\left[\mathrm{Mg}^{2+}\right]\left[\mathrm{CO}_{3}^{2-}\right]} .
$$

The above equilibrium constants refer to ion pairs but as it is known that $\mathrm{CaCO}_{3}$ pre-nucleation clusters are composed of an equal number of cations and anions [14], it is reasonable to assume similar conditions for $\mathrm{MgCO}_{3}$ pre-nucleation clusters. The determined constants for the formation of $\mathrm{CaCO}_{3}$ and $\mathrm{MgCO}_{3}$ pre-nucleation species in pure systems are in good agreement with previous studies [1921]. In an ideal system without the formation of mixed pre-nucleation clusters, one would expect that $\mathrm{Mg}^{2+}$ and $\mathrm{Ca}^{2+}$ containing species act independently from each other, so that the equilibrium constants do not change with altering $\mathrm{Mg} / \mathrm{Ca}$-ratios. The development of the formation constant of $\mathrm{CaCO}_{3}$ pre-nucleation species with rising $\mathrm{Mg}$ contents illustrates however that the presence of $\mathrm{Mg}^{2+}$ indeed influences the stability of $\mathrm{CaCO}_{3}$ pre-nucleation species (Fig. 2).

The higher the $\mathrm{Mg} / \mathrm{Ca}$-proportion the smaller is the formation constant $\mathrm{K}_{\mathrm{Ca}}$. The same trend can be observed for $\mathrm{MgCO}_{3}$ pre-nucleation species. This observation is unexpected when assuming that solely ion pairs or pure $\mathrm{MgCO}_{3}$ and $\mathrm{CaCO}_{3}$ pre-nucleation species are formed as the formation constants $\mathrm{K}_{\mathrm{Ca}}$ and $\mathrm{K}_{\mathrm{Mg}}$ had to be constant independently from the $\mathrm{Mg} / \mathrm{Ca}$-ratio in the solution. Though, a feasible explanation of this behaviour is that $\mathrm{Mg}^{2+}$ interacts with $\mathrm{CaCO}_{3}$ pre-nucleation species and vice versa.

Hence, exclusively pure $\mathrm{CaCO}_{3}$ and $\mathrm{MgCO}_{3}$ pre-nucleation species are obviously not formed in favour of mixed pre-nucleation cluster formation. This finding is understandable since $\mathrm{Mg}^{2+}$ and $\mathrm{Ca}^{2+}$ ions are chemically similar and can replace each other as the well-known example of Mg-calcite shows. After formation of mixed prenucleation clusters, the stability of the respective Ca-prenucleation species is apparently reduced. However, the question if there are two types of clusters, one high in $\mathrm{Ca}^{2+}$ and the other one enriched in $\mathrm{Mg}^{2+}$, cannot be solved on basis of the present data set. Nevertheless, a

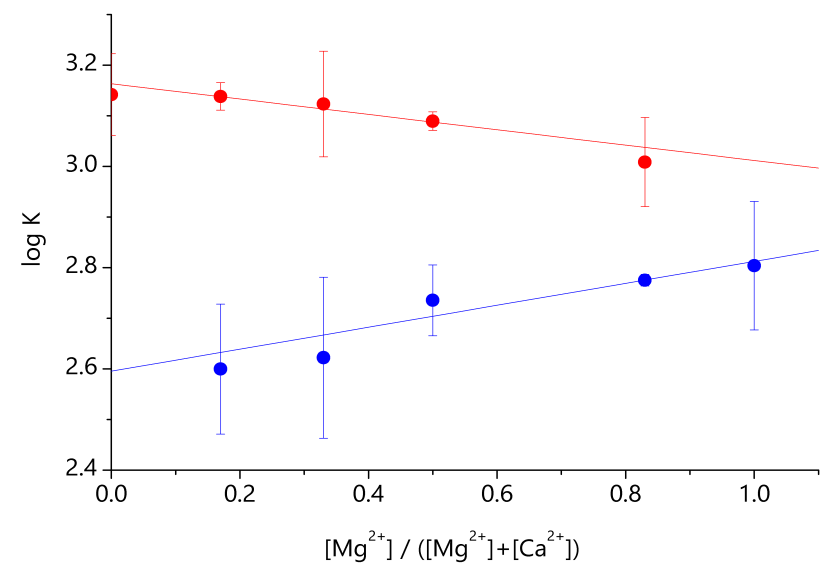

Fig. 2. Development of the equilibrium constants of $\mathrm{Mg}$ clusters (blue, squares) and $\mathrm{Ca}$ clusters (red, circles), respectively with changing magnesium mole fraction in the dosed solution. recent theoretical work has shown that $\mathrm{CaCO}_{3}$ pre-nucleation clusters are highly dynamic forming and dissociating polymeric species [22]. In turn, this means that two different pre-nucleation cluster species, one high in $\left[\mathrm{Ca}^{2+}\right]$ and one high in $\left[\mathrm{Mg}^{2+}\right]$ should not exist but on time average only a single mixed species with uniform composition.

Mixed pre-nucleation species, containing both $\mathrm{Mg}^{2+}$ and $\mathrm{Ca}^{2+}$ might also explain how ACC with high $\mathrm{Mg}^{2+}$ ratios can be formed since pre-nucleation clusters are the constituents of the then precipitated amorphous phase as indicated for $\mathrm{CaCO}_{3}[14,15]$.

In order to elucidate the existence of $\mathrm{MgCO}_{3}$ pre-nucleation clusters as well as mixed clusters, AUC-experiments were conducted in solely $\mathrm{Mg}^{2+}$ containing carbonate solutions as well as carbonate solutions containing both $\mathrm{Mg}^{2+}$ and $\mathrm{Ca}^{2+}$ ions (ratio 5:1). The recorded data were analyzed applying the model of discrete non-interacting species via fitting of the experimental data to the Lamm equation using the SEDFIT software [23]. In this model the mean value of the sedimentation coefficient $s$ is determined for up to 4 individual species in the solution as well as their diffusion coefficients and concentrations. The sedimentation coefficient is a measure for the sedimentation velocity of particles, which is linked among others to the molar mass, the density and the shape of the subject of investigation. Higher molar mass and/or density lead to a higher s-value. The results of the data analysis are shown in Fig. 3.

In the $\mathrm{MgCO}_{3}$-experiments 3 to 4 different species could be detected. The species $\left(\mathrm{S}_{1}\right)$ with the lowest sedimentation coefficient $\left(s_{1}<0.2 \mathrm{~S}\right)$ represent hydrated ions (magnesium, carbonate, sodium and chloride ions). Generally the resolution is too small to distinguish between different ion species and ion pairs. The next faster sedimenting species $\left(\mathrm{S}_{2}\right)$ exhibits a sedimentation coefficient of about 1.0 S. This species is too large to correlate it to a single hydrated ion species. In previous experiments on $\mathrm{CaCO}_{3}$, this species was assigned to the pre-nucleation clusters [14]. In addition, up to two even larger species could be detected in the present experiments. These spe-

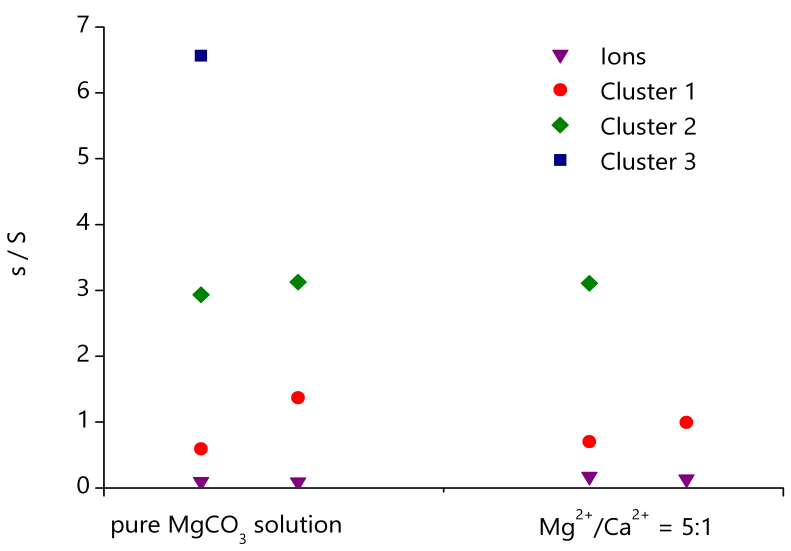

Fig. 3. Sedimentation coefficients $s$ obtained in analytical ultracentrifugation experiments on $\mathrm{Mg}^{2+}$ as well as $\mathrm{Mg}^{2+}$ and $\mathrm{Ca}^{2+}$ containing carbonate buffer solutions. The smallest $s$-value represents ions and ion pairs, which cannot be separated by means of AUC, while larger sedimentation coefficients represent different cluster species. The experiments were repeated twice for each sample and are displayed in columns. 
cies with a sedimentation coefficient $s_{3}$ and $s_{4}$ are formed by aggregation of the smaller pre-nucleation species as suggested in a previous work $[14,15]$. In general, the present results resemble those on the $\mathrm{CaCO}_{3}$ system [14]. Consequently, in carbonate solutions containing both $\mathrm{Mg}^{2+}$ and $\mathrm{Ca}^{2+}$ ions cluster species were found, too. The sedimentation coefficient of the species $s_{2}$ here again was around $s=1.0 \mathrm{~S}$. Hence, no significant differences to the experiments with pure $\mathrm{MgCO}_{3}$-solution could be detected. Due to the resolution limit of the AUC it is not possible to make any further statements about the mixed $\mathrm{Mg} / \mathrm{Ca}-$ pre-nucleation species.

\section{Conclusions}

In this study we revealed that in solutions of magnesium and carbonate ions pre-nucleation clusters are formed, as previously already had been shown for the $\mathrm{CaCO}_{3}$-system. In pure $\mathrm{MgCO}_{3}$ solutions different cluster species could be identified besides the expected ions. Experiments in solutions containing both magnesium and calcium ions showed that the stability of $\mathrm{CaCO}_{3}$ pre-nucleation species tends to decrease, when the $\mathrm{Mg}^{2+}$ ion concentration increases. The same trend was found for $\mathrm{MgCO}_{3}$ clusters in the presence of $\mathrm{Ca}^{2+}$ ions. This behavior cannot be explained when pure magnesium or calcium carbonate clusters are assumed. Hence, magnesium and calcium form mixed carbonate clusters. However, the formation constant of $\mathrm{CaCO}_{3}$ pre-nucleation species stays under all conditions by a factor of $>1$ larger than that of $\mathrm{MgCO}_{3}$. This means in turn, that mixed clusters are enriched in $\mathrm{Ca}^{2+}$ as compared to the solution composition over the entire range of possible cation mixing ratios with the exception of pure $\mathrm{Mg}^{2+}$. Thus, pre-nucleation clusters lead to a $\mathrm{Ca}^{2+}$ enrichment with an equilibrium constant, which is larger by a factor 1.5-4 over that of $\mathrm{MgCO}_{3}$ pre-nucleation clusters (see also Fig. 2) in the pre-nucleation clusters depending on the initial cation mixing ratio. A factor between these equilibrium constants of 1.78 for the $5: 1 \mathrm{Mg} / \mathrm{Ca}$ mixing ratio in seawater is found. Since the clusters are mixed with respect to both cations and carbonate is present in a large excess and thus constant for both equilibria, the enrichment of $\mathrm{Ca}^{2+}$ over $\mathrm{Mg}^{2+}$ in the clusters can be calculated by multiplying the equilibrium constants with the concentration of the respective free cations. For the $5: 1$ mixing ratio, this results in $26 \mathrm{~mol} \% \mathrm{Ca}^{2+}$ bound in the pre-nucleation clusters compared to the $17 \mathrm{~mol} \%$, resulting from the initial mixing ratio. However, this still gives a $\mathrm{Mg}^{2+}$ amount of $77 \mathrm{~mol} \%$ in the mixed pre-nucleation clusters for model seawater conditions. This is still much higher than the $41 \mathrm{~mol} \%$ maximum $\mathrm{Mg}$-content in biogenic $\mathrm{Mg}$-calcite [5]. Therefore, $\mathrm{Ca}^{2+}$ enrichment in pre-nucleation clusters is not the only factor to explain the enrichment of $\mathrm{Ca}^{2+}$ in biogenic magnesium calcite precipitated from seawater alone. Potential deviations may result from the fact that the $\mathrm{pH}$ of seawater is lower than the here applied $\mathrm{pH}=9.75$ or the situation that there are a number of further ions in real seawater, which may also get incorporated into mixed pre-nucleation clusters thus changing their stability.
The formation of calcium and magnesium mixed prenucleation clusters nevertheless illustrates how huge amounts of $\mathrm{Mg}^{2+}$ can be incorporated into amorphous $\mathrm{CaCO}_{3}$ with these pre-nucleation clusters being the nucleation relevant species and precursor of $\operatorname{ACC}[14,15]$. In the following crystallisation steps, hydration energies, lattice constraints or potentially present crystallisation modifiers may play a further key role in determining the polymorphism and the $\mathrm{Mg}$-content of the final crystal.

\section{Experimental section}

All experiments were performed at $24 \pm 1{ }^{\circ} \mathrm{C}$. The preparation of the solutions, the titration setup and the experimental procedure including the appropriate calibration procedures are described somewhere else in detail [14, 17]. The following chemicals were purchased and used without further purification: $1 \mathrm{~N} \mathrm{HCl}$ (No: 1.09057.1000; Merck) and $\mathrm{NaOH}$ (No: 1.09137.1000; Merck), $\mathrm{NaHCO}_{3}$ (99.7\%; No. 424270010; Acros Organics), $\mathrm{Na}_{2} \mathrm{CO}_{3}$ (anhydrous, 99.95\%; No. 223484; Sigma-Aldrich), $\mathrm{CaCl}_{2} \cdot 2 \mathrm{H}_{2} \mathrm{O}$ (99.5\%; No. 21097; Fluka) and $\mathrm{MgCl}_{2} \cdot 6 \mathrm{H}_{2} \mathrm{O}$ (>99\%, Roth, Nr. 2189.2). All experiments were performed in a beaker $(50 \mathrm{~mL})$ equipped with a stirring bar and filled with a carbonate buffer solution $(10 \mathrm{~mm})$ at $\mathrm{pH} 9.75$. Solutions containing $\mathrm{CaCl}_{2}(10 \mathrm{~mm})$ and $\mathrm{MgCl}_{2}$ in different ratios were preset to $\mathrm{pH}=9.75$ by addition of $10 \mathrm{~mm}$ $\mathrm{NaOH}$-solution (the dilution due to the $\mathrm{pH}$-adjustment is considered), and subsequently added to the buffer solution at a constant rate of $0.01 \mathrm{~mL} / \mathrm{min}$ while the $\mathrm{Ca}^{2+}$ and $\mathrm{Mg}^{2+}$-potentials were recorded by means of electrodes selective to the respective ions. The $\mathrm{pH}$-value is kept constant during the experiment via $\mathrm{pH}$-constant titration. After every experiment, beaker, burette tips and electrodes were washed with acetic acid (10\%) and carefully rinsed with distilled water. Analytical ultracentrifugation experiments were performed on a Beckman-Coulter XL-I Ultracentrifuge using Rayleigh interference optics at $25^{\circ} \mathrm{C}$ and 60,000 RPM. An experiment lasted at least $8 \mathrm{hr}$. AUC data were analysed using SEDFIT [23] software applying the model model of discrete non-interacting species.

Acknowledgements. We thank Antje Völkel, who conducted the AUC experiments and the data evaluation, as well as the Max-Planck Society for the financial support.

\section{References}

[1] E. Loste, R. M. Wilson, R. Seshadri, F. C. Meldrum, J. Cryst. Growth 2003, 254, 206-218.

[2] Y. Kitano, Bull. Chem. Soc. Jpn. 1962, 35, 1973-1980.

[3] S. Raz, S. Weiner, L. Addadi, Adv. Mater. 2000, 12, 38-42.

[4] A. Mucci, J. W. Morse, Geochimica Et Cosmochimica Acta 1983, 47, 217-233.

[5] J. H. Schroeder, E. J. Dwornik, J. J. Papike, Geol. Soc. Am. Bull. 1969, 80, 1613-1616.

[6] Y. R. Ma, B. Aichmayer, O. Paris, P. Fratzl, A. Meibom, R. A. Metzler, Y. Politi, L. Addadi, P. Gilbert, S. Weiner, Proc. Natl. Acad. Sci. USA 2009, 106, 6048-6053. 
[7] Y. Politi, D. R. Batchelor, P. Zaslansky, B. F. Chmelka, J. C. Weaver, I. Sagi, S. Weiner, L. Addadi, Chemistry of Materials 2010, 22, 161-166.

[8] D. B. Wang, A. F. Wallace, J. J. De Yoreo, P. M. Dove, Proc. Natl. Acad. Sci. USA 2009, 106, 21511-21516.

[9] S. Weiner, I. Sagi, L. Addadi, Science 2005, 309, 1027-1028.

[10] Y. Politi, T. Arad, E. Klein, S. Weiner, L. Addadi, Science 2004, 306, 1161-1164.

[11] DOE, Handbook of methods for the analysis of the various parameters of the carbon dioxide system in sea water, 2. ed., ORNL/CDIAC-74 1994

[12] J. Seto, Y. Ma, S. A. Davis, F. Meldrum, A. Gourrier, Y. Y. Kim, U. Schilde, M. Sztucki, M. Burghammer, S. Maltsev, C. Jäger, H. Cölfen, Proc. Natl. Acad. Sci. USA 2012, 109, 36993704.

[13] R. Money, C. W. Davies, Trans. Faraday Soc. 1932, 28, 609614.
[14] D. Gebauer, A. Völkel, H. Cölfen, Science 2008, 322, 18191822.

[15] E. M. Pouget, P. H. H. Bomans, J. Goos, P. M. Frederik, G. de With, N. Sommerdijk, Science 2009, 323, 1455-1458.

[16] D. Gebauer, H. Cölfen, Nano Today 2012, 6, 564-584.

[17] D. Gebauer, H. Cölfen, A. Verch, M. Antonietti, Adv. Mater. 2009, 21, 435-439.

[18] A. Verch, D. Gebauer, M. Antonietti, H. Colfen, Physical Chemistry Chemical Physics 2011, 13, 16811-16820.

[19] R. M. Siebert, P. B. Hostetler, Am. J. Sci. 1977, 277, 716-734.

[20] E. J. Reardon, D. Langmuir, Am. J. Sci. 1974, 274, 599-612.

[21] L. N. Plummer, E. Busenberg, Geochimica Et Cosmochimica Acta 1982, 46, 1011-1040.

[22] R. Demichelis, P. Raiteri, J. D. Gale, D. Quigley, D. Gebauer, Nature Communications 2012, 2.

[23] P. Schuck, Biophysical Journal 2000, 78, 1606-1619. 